\title{
Licochalcone A Inhibits MMPs and ADAMTSs via the NF-kB and Wnt/ $\beta$-Catenin Signaling Pathways in Rat Chondrocytes
}

\author{
Wei-Ping Chen ${ }^{a}$ Zhong-Nan Hu ${ }^{b} \quad$ Li-Bin Jin ${ }^{a} \quad$ Li-Dong Wu \\ aDepartment of Orthopedics Surgery, The Second Hospital of Medical College, Zhejiang University, \\ Hangzhou, bepartment of Orthopedics Surgery, The Children's Hospital of Medical College, Zhejiang \\ University, Hangzhou, China
}

\section{Key Words}

Osteoarthritis $•$ Licochalcone A $・$ Matrix metalloproteinase $\cdot N F-\kappa B \cdot \beta$-catenin

\begin{abstract}
Background: Osteoarthritis $(\mathrm{OA})$ is a joint disease in which cartilage degradation is the central pathological change. In this study, we investigated the anti-osteoarthritic effects of licochalcone A (Lico A) in rat chondrocytes. Methods: Polymerase chain reaction and Western blotting were performed to evaluate the expression of a disintegrin and metalloproteinase with thrombospondin motifs (ADAMTS)-5, ADAMTS-4, collagen II, matrix metalloproteinase (MMP)-13 and MMP-1 at both the gene and protein levels, respectively. In addition, the wnt/ $\beta$-catenin and nuclear factor kappa B (NF-KB) signaling pathways were also analyzed by Western blotting. Results: Lico A downregulated ADAMTS-5, ADAMTS-4,MMP-13 and MMP1 expression, and diminished the IL-1 $\beta$-induced inhibition of collagen II. In addition, the activation of $\beta$-catenin and phosphorylation of $p 65$ and IKK $\alpha / \beta$ were suppressed by Lico $A$. Conclusions: Our results suggest that Lico A inhibits MMPs and ADAMTS partly via the NF-KB and $w n t / \beta$-catenin signaling pathways in rat chondrocytes. Thus, Lico $A$ may have therapeutic effects in OA.

\section{Introduction}

Osteoarthritis (OA) is a common joint disease that often causes pain and disability, particularly in older people [1-4]. Many factors such as mechanical, biochemical, and enzymatic factors are involved in its onset [5] .However, the mechanisms underlying this disease are still unclear. As a pro-inflammatory cytokine, interleukin-1beta (IL-1ß) leads to the apoptosis of chondrocytes and degradation of the extracellular matrix (ECM), which results in cartilage degeneration [6-8]. Previous studies have shown that the degeneration 


\section{Cellular Physiology Cell Physiol Biochem 2017;43:937-944 \begin{tabular}{ll|l} 
DOI: 10.1159/000481645 & $\begin{array}{l}\text { O 2017 The Author(s). Published by S. Karger AG, Basel } \\
\text { www.karger.com/cpb }\end{array}$ \\
\hline and Biochemistry
\end{tabular}}

of cartilage may be associated with matrix metalloproteinases (MMPs), a disintegrin and metalloproteinase with thrombospondin motifs (ADAMTS), and other catabolic enzymes [9]. MMP-1 and MMP-13 can cleave collagen II, whereas ADAMTS-4 and ADAMTS-5 can degrade the aggrecan in cartilage [10-13]. Nonsteroidal anti-inflammatory drugs(NSAIDs) are still the primary treatment for $\mathrm{OA}$; however, they can not protect the cartilage from further damage $[14,15]$. Thus, new effective agents that can protect joint structure and function are still needed.

Flavonoids are plant-derived compounds that can be purified from vegetables, fruits, and medical herbs [16]. Licochalcone A (Lico A) is a flavonoid isolated from licorice or Glycyrrhiza inflate [17]. It possesses a variety of pharmaceutical activities including antiinflammatory, anti-oxidative, and anti-tumor properties [18-21]. Moreover, a recent study revealed that Lico A can suppress MMP expression [22]. Therefore, it may be a potential treatment for OA. However, little is known about the anti-osteoarthritic effects of Lico A in chondrocytes. In this study, we examined the anti-osteoarthritic effects of Lico A in IL-1 $\beta$ stimulated rat chondrocytes. The activation of wnt/ $\beta$-catenin and nuclear factor kappa $B$ (NF- $\mathrm{KB}$ ) signaling pathways was also investigated to determine the probable regulatory mechanisms.

\section{Materials and Methods}

\section{Reagents}

Lico A, dimethylsulfoxide (DMSO), and IL-1 $\beta$ were purchased from Sigma-Aldrich (St Louis, MO, USA). Dulbecco's Modified Eagle's Medium (DMEM), 3-(4, 5-dimethylthiazolyl-2)-2, 5-diphenyltetrazolium bromide (MTT), fetal bovine serum (FBS), penicillin, streptomycin, and $0.25 \%$ trypsin, collagenase II were purchased from Gibco BRL (Grand Island, NY, USA).

\section{Cell culture}

With approval of the Institutional Animal Care and Use Committee of Zhejiang University (Hangzhou, China), articular cartilage was obtained from the knees and femoral heads of rats (Zhejiang Academy of Medical Sciences, Hangzhou, China). After digestion with $0.25 \%$ trypsin for $15 \mathrm{~min}$, the cartilage was incubated with $1 \mathrm{mg} / \mathrm{mL}$ collagenase II at $37^{\circ} \mathrm{C}$ for $3 \mathrm{~h}$. Then chondrocytes were separated from the cartilage and cultured in $25 \mathrm{~cm}^{2}$ flasks in DMEM with $10 \% \mathrm{FBS}, 100 \mathrm{U} / \mathrm{mL}$ penicillin, and $100 \mu \mathrm{g} / \mathrm{mL}$ streptomycin at $37^{\circ} \mathrm{C}$ with $5 \% \mathrm{CO}_{2}$. These cells were considered passage 0 (P0). Once they reached confluence, the chondrocytes were split in a 1:3 ratio. P3 cells were used for analysis.

Cell viability assay

Cells were cultured in a 96-well plate $\left(5 \times 10^{3}\right.$ cells/well) with various concentrations of Lico A and IL-1 $\beta(10 \mathrm{ng} / \mathrm{mL})$ for $24 \mathrm{~h}$. Then, $20 \mu \mathrm{L}$ per well of MTT $(5 \mathrm{mg} / \mathrm{mL})$ was added to each well for $4 \mathrm{~h}$ at $37^{\circ} \mathrm{C}$. The culture medium was removed before adding $150 \mu \mathrm{L} /$ well DMSO. Finally, the absorbance at $570 \mathrm{~nm}$ was measured using a microplate reader (Bio-Rad, Hercules, CA, USA). Cell viability was determined using the MTT assay aspreviously described [23]. All of the assays were performed in triplicate.

\section{Cells treatment}

Chondrocytes were serum-starved for $12 \mathrm{~h}$ before seeding into six-well plates at an initial density of $2 \times 10^{5}$ cells/well. The cells were pretreated with Lico A $(0,1,5,10 \mu \mathrm{M})$ for $1 \mathrm{~h}$ followed by IL- $1 \beta(10 \mathrm{ng} / \mathrm{mL})$ stimulation for $24 \mathrm{~h}$ to analyze the expression of MMPs, ADAMTS, and collagen II. Other chondrocytes were cultured in $60 \mathrm{~mm}$ dishes at an initial density of $5 \times 10^{5}$ cells/well, and pretreated with Lico A $(0,1,5,10 \mu \mathrm{M})$ for $2 \mathrm{~h}$ followed by IL-1 $\beta(10 \mathrm{ng} / \mathrm{mL})$ stimulation for $30 \mathrm{~min}$ to investigate activation of the wnt $/ \beta$-catenin and NF- $\mathrm{\kappa B}$ signaling pathways.

Quantitative real-time polymerase chain reaction ( $q R T-P C R$ )

Total RNA was extracted and purified using TRIzol@ Plus RNA Purification Kit (Invitrogen, Carlsbad, CA, USA) and RNase-Free DNase Set (QIAGEN Translational Medicine Co., Ltd., Wilmington, DE). The Su- 
perScript $^{\mathrm{TM}}$ III First-Strand Synthesis SuperMix for qRT-PCR Kit (Invitrogen) was used to reverse transcribe total RNA to complementary DNA (cDNA) following the manufacturer's instructions. The amplification of MMPs, ADAMTS, and collagen II was performed using the Power SYBR $\AA$ Green PCR Master Mix kit (Applied Biosystems, Foster City, CA, USA) under conditions of $95^{\circ} \mathrm{C}$ for $10 \mathrm{~min}$, followed by 40 cycles at $95^{\circ} \mathrm{C}$ for $15 \mathrm{~s}$ and $60^{\circ} \mathrm{C}$ for $60 \mathrm{~s}$ [24]. To normalize expression, 18S rRNA was amplified as an internal control. The primers used are shown in Table 1. All of the experiments were performed according to the manufacturer's protocol in triplicate using three independent samples. Quantitative real-time PCR (qPCR) data were calculated using the $2^{(-\Delta \Delta \mathrm{CT})}$ method.

\section{Western blot analysis}

Cells were washed using ice-cold phosphatebuffered saline followed by addition of $40 \mu \mathrm{L}$ RIPA buffer containing $0.4 \mu \mathrm{L}$ protease inhibitors for 30 min to extract all of the proteins. Then the mixture was centrifuged and quantified using a BCA Protein Assay kit (Beyotime Biotechnology, Shanghai, China), and electrotransferred to nitrocellulose membranes. The membranes were incubated with Tris-buffered saline with tween (TBS-T) for $1 \mathrm{~h}$ and cut into sections based on protein molecular weights. Then the membranes were incubated with primary antibodies against ADAMTS-5, ADAMTS-4, collagen II, MMP13, MMP-1, $\beta$-ctenin, $\beta$-actin, (Santa Cruz Biotech, Inc., Dallas, TX, USA), IкB alpha, p-IKK alpha/beta, IKK alpha/beta, p-65, and p-p65 (Abcam Inc., Cambridge, UK) for $12 \mathrm{~h}$ at $4^{\circ} \mathrm{C}$. After washing with TBS-T, the membranes were incubated with secondary antibodies (Thermo Fisher, Waltham, MA, USA) at $25^{\circ} \mathrm{C}$ for 1 $\mathrm{h}$. The membranes were washed again with TBS-T, and immunoreactive bands were detected by enhanced chemiluminescence (Thermo Fisher) and exposure to X-ray film (Kodak, Hangzhou, China) for densitometry analysis (BandScan 5.0 sofware). All of the assays were performed in triplicate.

\section{Statistical analysis}

All data are expressed as the mean \pm SD. Data were analyzed using one-way ANOVA. Dunnett's test was used as the post-test for ANOVA. Differences were considered statistically significant when $\mathrm{P}<0.05\left({ }^{*}\right)$ or $\left.\mathrm{P}<0.01{ }^{* *}\right)$.

\section{Results}

Effects of Lico A on chondrocyte viability

MTT assays revealed that Lico A had no cytotoxicity at a concentration of $10 \mu \mathrm{M}$ (Fig.1); thus, this was the concentration used in subsequent experiments. 


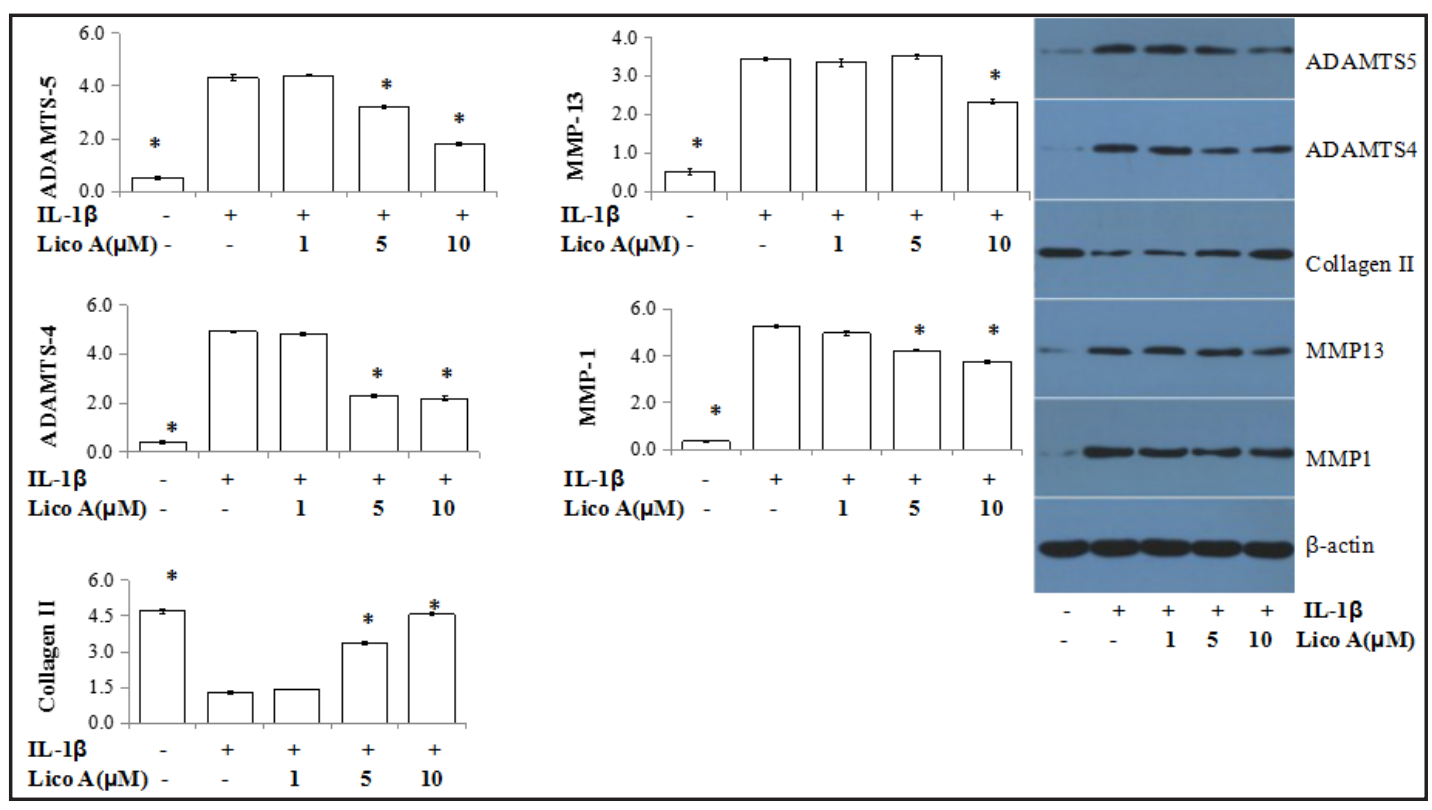

Fig. 2. Effects of Lico A on the gene expression of ADAMTS-5, ADAMTS-4, Collagen II, MMP-1 and MMP13. Samples were pretreated with various concentrations of Lico A. The mRNA expressions of ADAMTS-5, ADAMTS-4, MMP-13, and MMP-1 decreased and collagen II levels increased in a dose-dependent manner after Lico A treatment. ${ }^{* *} \mathrm{P}<0.01$ compared to cells stimulated with IL-1 $\beta$ in the absence of Lico A.

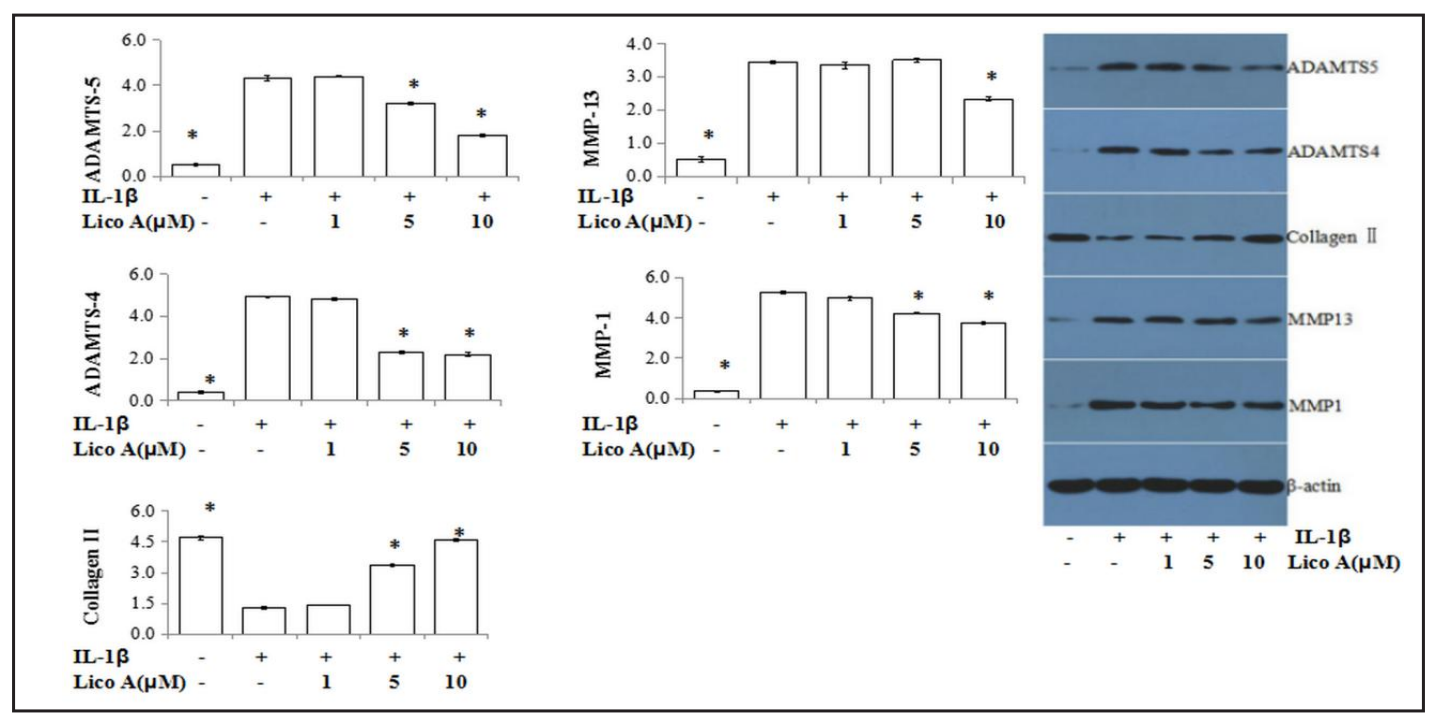

Fig. 3. Effects of Lico A on the protein expression of ADAMTS-5, ADAMTS-4, Collagen II, MMP-13, and MMP1. Samples were pretreated with various concentrations of Lico A. Densitometry was performed to analyze the ratio of the density between the protein and $\beta$-actin. ${ }^{*} \mathrm{P}<0.05$ compared to samples stimulated with IL-1 $\beta$ in the absence of Lico A.

Effects of Lico A on ADAMTS-5, ADAMTS-4, Collagen II, MMP-13 and MMP-1 expression in chondrocytes

qPCR was performed to measure the mRNA expression of ADAMTS-5, ADAMTS-4, collagen II, MMP-13, and MMP-1 in IL-1 $\beta$-stimulated chondrocytes. The expression of ADAMTS-5, ADAMTS-4, MMP-13 and MMP-1 was decreased and the expression of collagen II was increased by Lico A in a dose-dependent manner (Fig. 2). Western blot analysis revealed 


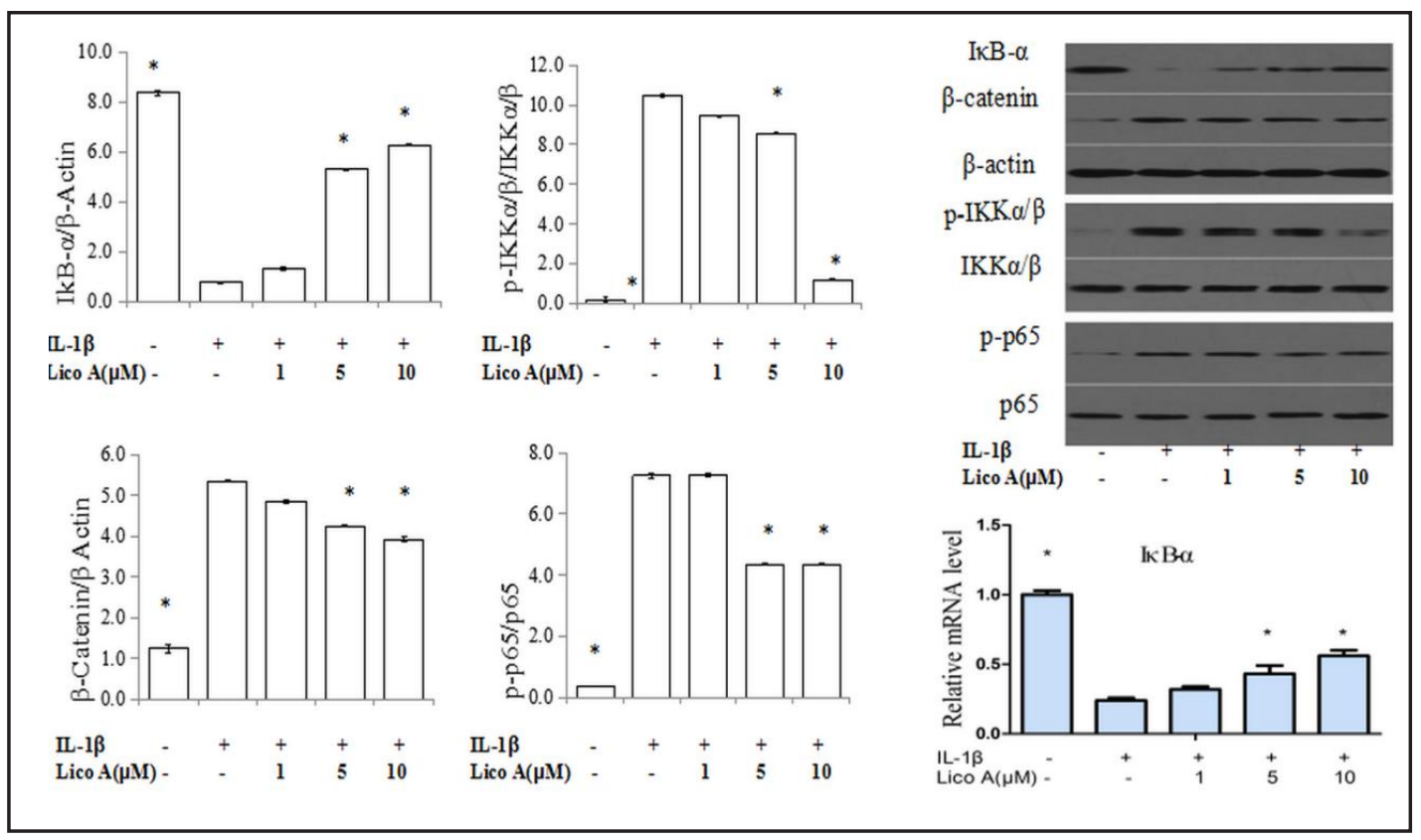

Fig. 4. Effects of Lico $A$ on the NF- $\kappa B$ and Wnt/ $\beta$-catenin signaling pathways. Samples were pretreated with Lico A $(0,1,5,10 \mu \mathrm{M})$ for $2 \mathrm{~h}$ followed by IL-1 $\beta(10 \mathrm{ng} / \mathrm{mL})$ for $30 \mathrm{~min}$. Densitometry was performed to analyze the ratios of the density between phosphorylated p65 and p65, and between phosphorylated $\mathrm{IKK} \alpha / \beta$ and IKK $\alpha / \beta$. The expression of IKB- $\alpha$ and $\beta$-catenin was compared to $\beta$-actin. The mRNA levels of I $\mathrm{B}-\alpha$ were also investigated. ${ }^{*} \mathrm{P}<0.05$ compared to samples stimulated with IL-1 $\beta$ in the absence of Lico A.

that the protein expression of ADAMTS-5, ADAMTS-4, collagen II, MMP-13 and MMP-1 was similar to the mRNA expression (Fig. 3).

\section{Effects of Lico A on $N F-\kappa B$ and wht/ $\beta$-catenin signaling pathways}

We also investigated the effects of Lico $A$ on both the NF- $\kappa B$ and wnt $/ \beta$-catenin signaling pathways, and found that IL-1 $\beta$ activated both pathways. However, treatment with Lico A reduced the activation of both pathways, and p-IKK $\alpha, \beta, \mathrm{p}$-p65, and $\beta$-catenin levels were

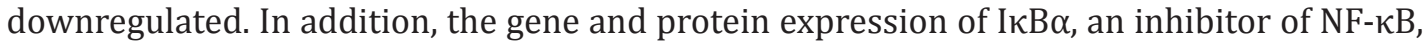
significantly increased after Lico A treatment (Fig. 4).

\section{Discussion}

In this study, we investigated the effects of Lico A on IL-1 $\beta$-stimulated chondrocytes, and found that Lico A reduced expression of ADAMTS-5, ADAMTS-4, MMP-13 and MMP-1 in rat chondrocytes. In addition, the expression of collagen II was upregulated by Lico A.

Collagen II is an important component of the ECM, and the expression of collagen II is decreased in OA. Therefore, inhibiting collagen II degradation is a strategy for OA treatment. In this study, IL-1 $\beta$ stimulation resulted in reduced collagen II expression. However, Lico A upregulated the expression of collagen II, which suggests that Lico A has protective effects in chondrocytes.

In OA, enzymes are secreted that degrade the ECM including ADAMTS-5, ADAMTS-4, MMP-13, and MMP-1. These enzymes can cleave collagen II and aggrecan in cartilage. Thus, downregulation of these enzymes could be beneficial to cartilage [25, 26]. In this study, stimulation of IL-1 $\beta$ resulted in the increased expression of ADAMTS-5, ADAMTS-4, MMP-13, and MMP-1. Lico A significantly inhibited the upregulation of ADAMTS-5, ADAMTS-4, MMP13 , and MMP-1 in chondrocytes. In addition, Lico A diminished the IL-1 $\beta$-induced inhibition 
of collagen II expression. A previous study reported that Lico A inhibits the expression of MMP-1 and MMP-3 in human lung cancer cells [22]. Our results demonstrate that Lico A has anti-catabolic properties in rat chondrocytes.

The importance of the NF- $\mathrm{B}$ pathway in the inflammatory process has been well established. Recently, Zhou et al. reported that by controlling the activation of NF- $\kappa B$ signaling, IL-1 $\beta$ can modulate ADAMTS expression [27]. Moreover, the critical role of NF- $\kappa B$ in the regulation of MMP expression has also been recognized $[28,29] .$. For NF- $\kappa B$ activation, inhibitors of $\kappa \mathrm{B}(\mathrm{I} \kappa \mathrm{B})$ are ubiquitinated after phosphorylation by IKK, which releases NF- $\kappa \mathrm{B}$ dimers, after which p50 and p65 heterodimers are released [30-32]. In this study, we found that IL-1 $\beta$ stimulation resulted in activation of the NF- $\kappa B$ pathway, and that Lico A significantly suppressed the phosphorylation of IKK $\alpha / \beta$ and p 65 and increased I $\mathrm{KB} \alpha$ expression. These results suggest that the NF- $\kappa B$ pathway may be involved in the downregulation MMPs and ADAMTS by Lico A in IL-1 $\beta$-stimulated chondrocytes.

The wnt/ $\beta$-catenin signaling pathway is related to cartilage homeostasis and joint remodeling [33]. In addition, a previous study showed that $\beta$-catenin was overexpressed in joint tissues from OA patients and animals [7]. In this study, the expression of $\beta$-catenin was significantly downregulated by Lico A in chondrocytes. Thus, we speculated that the anticatabolic effects of Lico A may partly occur through inhibition of the wnt/ $\beta$-catenin signaling pathway.

\section{Conclusion}

This study demonstrated that Lico A can inhibit IL-1 $\beta$-induced ADAMTS-5, ADAMTS-4, MMP-13, and MMP-1 expression at both the gene and protein levels in rat chondrocytes. Moreover, the NF- $\kappa B$ and wnt/ $\beta$-catenin signaling pathways may be involved in this process. Thus, Lico A may be a potential treatment for OA.

\section{Acknowledgements}

This study was supported by the National Natural Science Foundation of China (81371996 and 81572173 ).

\section{Disclosure Statement}

The authors declare that there are no conflicts of interest.

\section{References}

1 Dubin A: Managing Osteoarthritis and Other Chronic Musculoskeletal Pain Disorders. Med Clin North Am 2016;100:143-150.

-2 Kevorkian L, Young DA, Darrah C, Donell ST, Shepstone L, Porter S, Brockbank SMV, Edwards DR, Parker AE, Clark IM: Expression profiling of metalloproteinases and their inhibitors in cartilage. Arthritis Rheum 2004;50:131-141.

-3 Silverwood V, Blagojevic-Bucknall M, Jinks C, Jordan JL, Protheroe J, Jordan KP: Current evidence on risk factors for knee osteoarthritis in older adults: a systematic review and meta-analysis. Osteoarthritis Cartilage 2015;23:507-515.

4 Felson DT: Epidemiology of hip and knee osteoarthritis. Epidemiol Rev 1988;10:1-28.

5 Priyanka V,Krishna D: ADAMTS-4 and ADAMTS-5: Key Enzymes in Osteoarthritis. J Cell Biochem 2011;112:3507-3514. 


\section{Cellular Physiology Cell Physiol Biochem 2017;43:937-944 \begin{tabular}{ll|l} 
DOI: 10.1159/000481645 & $\begin{array}{l}\text { O } 2017 \text { The Author(s). Published by S. Karger AG, Basel } \\
\text { wwww.karger.com/cpb }\end{array}$
\end{tabular}

6 Pasternak B, Aspenberg P: Metalloproteinases and their inhibitors-diagnostic and therapeutic opportunities in orthopedics. Acta Orthop 2009;80:693-703.

7 Jin L, Xin-die Z, Kong-he Y, Teng-di F, Wei-ping C, Li-feng J, Bao JP, Wu LD, Xiong Y: Hinokitiol reduces matrix metalloproteinase expression by inhibiting Wnt/ $\beta$-Catenin signaling in vitro and in vivo. Int Immunopharmacol 2014;23: 85-91.

-8 Chen WP, Xiong Y, Shi YX, Hu PF, Bao JP,Wu LD: Astaxanthin reduces matrix metalloproteinase expression in human chondrocytes. Int Immunopharmacol 2014;19:174-177.

-9 Santangelo KS, Nuovo GJ, Bertone AL: In vivo reduction or blockade of interleukin-1beta in primary osteoarthritis influences expression of mediators implicated in pathogenesis. Osteoarthritis Cartilage 2012;20:1610-1618.

10 Bramono DS, Richmond JC, Weitzel PP, Kaplan DL, Altman GH: Matrix metalloproteinases and their clinical applications in orthopaedics. Clin Orthop Relat Res 2004;428:272-285.

-11 Tortorella MD, Burn TC, Pratta MA, Abbaszade I, Hollis JM, Liu R, Rosenfeld SA, Caspers N, Wittwer AJ, Malfait A-M, Shieh H-S: Purification and cloning of aggrecanase-1: A member of the ADAMTS family of proteins. Science 1999;284:1664-1666.

-12 Tortorella MD, Pratta M, Liu RQ, Austin J, Ross OH, Abbaszade I, Burn T, Arner E: Sites of aggrecan cleavage by recombinant human aggrecanase-1 (ADAMTS-4). J Biol Chem 2000; 275:18566-18573.

13 Gendron C, Kashiwagi M, Lim NH, Enghild JJ, Thøgersen IB, Hughes C, Caterson B, Nagase H: Proteolytic activities of human ADAMTS-5: Comparative studies with ADAMTS-4. J Biol Chem 2007;282:18294-18306.

14 Felson DT, Kim Y-J: The futility of current approaches to chondroprotection. Arthritis Rheum 2007;56:1378-1383.

15 Crofford LJ, Lipsky PE, Brooks P, Abramson SB, Simon LS, van de Putte LB: Basic biology and clinical application of specific cyclooxygenase-2 inhibitors. Arthritis Rheum 2000;43:4-13.

16 Dixon RA, Steele C L: Flavonoids and isoflavonoids-a gold mine for metabolic engineering. Trends Plant Sci 1999;4:394-400.

17 Hatano T, Kagawa H, Yasuhara T, Okuda T: Two new flavonoids and other constituents in licorice root: their relative astringency and radical scavenging effects. Chem Pharml Bull 1988;36:2090-2097.

18 Kwon HS, Park JH, Kim DH, Kim YH, Park JH, Shin HK, Kim JK: Licochalcone a isolated from licorice suppresses lipopolysaccharide-stimulated inflammatory reactions in RAW264.7 cells and endotoxin shock in mice. J Mol Med 2008;86:12871295.

19 Bortolotto LF, Barbosa FR, Silva G, Bitencourt TA, Beleboni RO, Baek SJ, Marins M, Fachin AL: Cytotoxicity of trans-chalcone and licochalcone A against breast cancer cells is due to apoptosis induction and cell cycle arrest. Biomed Pharmacother 2017;85:425-433.

20 Hongming Lv, Hua Ren, Lidong Wang, Wei Chen, Xinxin Ci: Lico A Enhances Nrf2-Mediated Defense Mechanisms against t-BHP-Induced Oxidative Stress and Cell Death via Akt and ERK Activation in RAW 264.7 Cells. Oxid Med Cell Longev 2015; 2015: 709845.

-21 Egler J, Lang F: Licochalcone A Induced Suicidal Death of Human Erythrocytes. Cell Physiol Biochem 2015;37:2060-2070.

-22 Huang HC, Tsai LL, Tsai JP, Hsieh SC, Yang SF, Hsueh JT, Hsieh YH: Licochalcone A inhibits the migration and invasion of human lung cancer cells via inactivation of the Akt signaling pathway with down regulation of MMP-1/-3 expression. Tumour Biol 2014;35:12139-12149.

23 Ding Q, Zhong H, Qi Y, Cheng Y, Li W, Yan S, Wang X: Anti-arthritic effects of crocin in interleukin-1 $\beta$-treated articular chondrocytes and cartilage in a rabbit osteoarthritic model. Inflamm Res 2013;62:17-25.

-24 Wei-Ping C, Zhi-Gao Y, Peng-Fei H, Jia-Peng B, Li-Dong W: Acacetin inhibits expression of matrix metalloproteinases via a MAPK-dependent mechanism in fibroblast-like synoviocytes. J Cell Mol Med 2015;19:1910-1915.

25 Du G, Song Y, Wei L, Li L, Wang X, Xu Q, Zhan H, Cao Y, Zheng Y, Ding D: Osthole Inhibits Proliferation and Induces Catabolism in Rat Chondrocytes and Cartilage Tissue. Cell Physiol Biochem 2015;36:2480-2493.

-26 Chen WP, Xiong Y, Hu PF, Bao JP, Wu LD: Baicalein Inhibits MMPs Expression via a MAPK-Dependent Mechanism in Chondrocytes. Cell Physiol Biochem 2015; 36: 325-333.

27 Sun Z1, Yin Z, Liu C, Liang H, Jiang M, Tian J: IL-1 $\beta$ promotes ADAMTS enzyme-mediated aggrecan degradation through NF- $\kappa$ B in human intervertebral disc. J Orthop Surg Res 2015; 10:159. 


\section{Cellular Physiology Cell Physiol Biochem 2017;43:937-944 and Biochemistry DOI: 10.1159/000481645 29, 2017 O 2017 The Author(s). Published by S. Karger AG, Basel

-28 Mengshol JA, Vincenti MP, Coon CI, Barchowsky A, Brinckerhoff CE: Interleukin-1 induction of collagenase 3 (matrix metalloproteinase 13) gene expression in chondrocytes requires p38, c-Jun N-terminal kinase, and nuclear factor kappaB: differential regulation of collagenase 1 and collagenase 3. Arthritis Rheum 2000;43:801-811.

29 Han ZN, Boyle DL, Manning AM, Firestein GS: AP-1 and NF-kappa B regulation in rheumatoid arthritis and murine collagen-induced arthritis. Autoimmunity 1998;28:197-208.

-30 Tak PP, Firestein GS: NF-кB: a key role in inflammatory diseases, J Clin Invest. 2001;107:7-11.

-31 Schottelius AJ, Mayo MW, Sartor RB, Baldwin AS, Jr: Interleukin-10 signaling blocks inhibitor of kappaB kinase activity and nuclear factor kappaB DNA binding. J Biol Chem 1999;274:31868-31874.

32 Vincenti MP, Coon CI, Brinckerhoff CE: Nuclear factor kappaB/p50 activates an element in the distal matrix metalloproteinase 1 promoter in interleukin-1beta-stimulated synovial fibroblasts. Arthritis Rheum 1998;41:1987-1994.

33 Chen M, Zhu M, Awad H, Li TF, Sheu TJ, Boyce BF, Chen D, O’Keefe RJ: Inhibition of beta-catenin signaling causes defects in postnatal cartilage development. J Cell Sci 2008;121:1455-1465. 